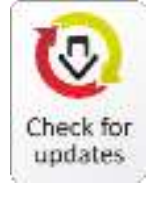

Article Type: Research Paper

\title{
MAPPING CANVAS BUSINESS MODELS FOR MARKETING LOUD WISE LEATHER PRODUCTS
}

\author{
Ahmad Azmy, Adrian Saputra, and R. Hario Sulistianto
}

\section{금opery}

\section{AFFILIATION:}

Tanri Abeng University, Jakarta, Indonesia.

\section{*CORRESPONDENCE: \\ azmy33@gmail.com}

THIS ARTICLE IS AVALILABLE IN:

http://journal.umy.ac.id/index.php/mb

DOI: $10.18196 / \mathrm{mb} .10174$

\section{CITATION:}

Azmy, A., Saputra, A., \& Sulistianto, R. H. (2019). Mapping Canvas Business Models for Marketing Loud Wise Leather Products. Jurnal Manajemen Bisnis, 10(2), 145-153.
Abstract: This study analyzes the canvas business model application for the needs of Loud Wise's marketing strategy. The research problem found that Loud Wise must maintain the existence of products with intense business competition. The canvas business model element, combined with the marketing mix mapping, was able to map the problem and recommended marketing strategies according to product needs. The recommendations given are increasing product promotion and giving new prices to consumers. The recommendation process through marketing analysis was using the SWOT Analysis approach. Companies must prioritize handmade-based production and increase product promotion to consumers. The use of social media must be used massively so that the increase in market growth is in line with the company's business targets.

Keywords: Business Model Canvas; Marketing Strategy; Business Sustainability.

\section{Introduction}

Development can be interpreted as an attempt to improve the conceptual, theoretical, technical, and moral abilities of individuals in accordance with the needs of work or position through education and training. The development of SMEs is more directed to become a competitive economic actor through the strength of entrepreneurship and increased productivity and supported by efforts to increase adaptation to market needs, the use of innovation, and the application of technology (Afifuddin, 2014). The influence of the development of MSME in Indonesia is by looking at the role of the government in increasing the growth of MSME in Indonesia, which has positive results, both directly and indirectly (Tambunan, 2013).

Karakaya, Badun, and Aytekin (2012) explained that marketing strategies aim to increase company sales through sociological and psychological influences that are precisely created for consumers. The product value can be felt by consumers when they compare the performance of the product based on its utility with the costs incurred (acquisition cost), for example, financial, psychological, and efforts to obtain the product (Oliver, 2015). Customer value received by consumers is defined as the difference between the total value received by consumers from products and services 


\author{
Azmy, Saputra, \& Sulistianto \\ Mapping Canvas Business Models for Marketing Loud Wise Leather Products
}

and the total costs incurred to obtain and use goods and services (Zeithaml, 2010; Lovelock, 2015).

UD. SARLEC \& SON'S is a subsidiary of PT. Heaven International, which is engaged in the development division of finish good products, especially those that form an MSME for the development of human resources in the leather industry in Sidoarjo, especially those who have expertise in producing leather. The company's vision is to make domestic products go international. Its mission is to produce international-class products and ensure the products produced become quality products. This company manufactures a product called Loud Wise. So far, LOUD WISE has products that can be compared to other companies' brands. Production results can be seen in terms of raw materials, painting results, and stitches that are not inferior to competitors.

This research would discuss and analyze the business model canvas to be used as a marketing strategy mapping for Loud Wise products. This mapping was expected to help increase profits for companies and business development for UD. SARLEC SON'S. The results of the mapping of the marketing strategy would be made a recommendation for business units to make changes to the production system according to market needs.

\title{
Literature Review and Hypotheses Development
}

Kotler and Keller (2007) state that the notion of marketing is a social and managerial process in which some individuals and groups get what they need and want by creating, offering, and exchanging products of value with other parties. Marketing strategies can refer to a process or result. The marketing strategy mostly discusses the process of formulating, implementing, and maintaining a marketing strategy. A complete marketing strategy will define every important aspect of the way the company enters the market. A good strategy will ultimately reduce the target to meet some specific needs of certain customers for competition in a profitable relationship (Tood, 2012).

A customer-driven marketing strategy is a very significant concept of marketing activities to maintain and make loyal customers (Abedin, Rahman, \& Mohiuddin, 2016). Kumar and Petersen (2005) revealed that marketing strategies must adapt to consumer needs. Marketing must have high responsiveness with the latest market trends. It can be mapped through the Business Model Canvas. Osterwalder and Pigneur (2012) explain that the Business Model Canvas is a business model describing thinking about how organizations create, deliver, and capture value.

Market segmentation is a process of placing consumers into subgroups that have the same response to a marketing program (Cravens, 1997). Targeting is the process of evaluating segmentation and focusing marketing strategies in a country, province, or group of people who have the potential to respond (Keegan \& Green, 2008). Kotler and Keller (2007) explained that product differentiation is the act of designing a series of meaningful differences to distinguish a company's offer from a competitor's offer. 
Product differentiation can be divided into forms, features, quality of performance, quality of conformity, durability, reliability, easily repaired.

Therefore, the conceptual framework of this study is as follows:

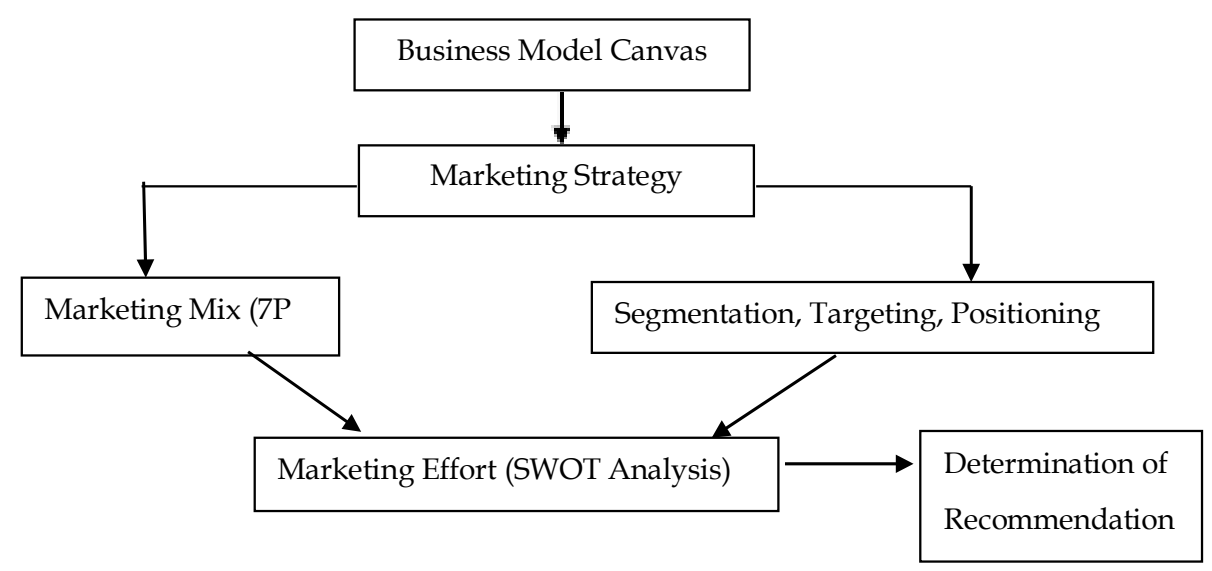

Figure 1 Conceptual Framework

\section{Research Method}

This research used a qualitative approach. Qualitative research is a study that intends to understand phenomena about what is experienced by research subjects such as behavior, perception, motivation, action holistically, and using description in the form of words and language in a special natural context and utilizing various natural methods (Tohirin, 2012).

According to Hanurawan (2012), case study research is research that uses a variety of methods and data sources. It means that in a case study research, the methodological approach (data collector tool) is eclectic (the use of data collection tools that help research purposes). Johnson and Christensen (2004) revealed that the purpose of case study research is a description of the context and occurrence of a case. The process of collecting data was using interview sources or informants who had the potential to provide information that was relevant to the actual situation in the field.

\section{Result and Discussion}

This study conducted several analyzes in accordance with research needs. The initial process was carried out by conducting observations and interviews with several informants related to Loud Wise products. Based on the results of the research process through observation and interviews, the canvas business model for the product is as follows: 
Azmy, Saputra, \& Sulistianto

Mapping Canvas Business Models for Marketing Loud Wise Leather Products

\begin{tabular}{|c|c|c|c|c|}
\hline \multicolumn{5}{|c|}{ Canvas SARLEC \& SON'S Model Canvas } \\
\hline \multirow[t]{2}{*}{$\begin{array}{l}\text { Key Partner } \\
\text { - } \text { raw } \\
\text { material } \\
\text { suppliers } \\
\text { - } \text { tailor } \\
\text { craftsman } \\
\text { - } \text { personal } \\
\text { reseller }\end{array}$} & $\begin{array}{l}\text { Key Activities } \\
\text { - making product } \\
\text { samples } \\
\text { - sales through } \\
\text { online, or endorse } \\
\text { - make a new model } \\
\text { - News updates to } \\
\text { customers }\end{array}$ & $\begin{array}{l}\text { Value } \\
\text { Proposition } \\
\text { - The wallet } \\
\text { uses the } \\
\text { primary } \\
\text { material of } \\
\text { genuine } \\
\text { leather } \\
\text { - varied } \\
\text { design } \\
\text { handmade } \\
\text { products }\end{array}$ & $\begin{array}{l}\text { Customer } \\
\text { Relationship } \\
\text { - customer } \\
\text { interaction with } \\
\text { online media/call } \\
\text { centers } \\
\text { - discounts on repeat } \\
\text { purchases } \\
\text { - receive complaints } \\
\text { and improvements }\end{array}$ & $\begin{array}{l}\text { Customer } \\
\text { Segment } \\
\text { - young men } \\
\text { and } \\
\text { women } \\
\text { ranging } \\
\text { from } \\
\text { young } \\
\text { people } \\
\text { (teenagers) } \\
\text { to the } \\
\text { elderly (50 } \\
\text { years and } \\
\text { over) }\end{array}$ \\
\hline & $\begin{array}{l}\text { Key Resource } \\
\text { - physical office } \\
\text { - private capital } \\
\text { - legal production } \\
\text { permit }\end{array}$ & & $\begin{array}{l}\text { Channels } \\
\text { - Instagram } \\
\text { - Facebook } \\
\text { - Call Center (WA< } \\
\text { BBM, Line, Email) }\end{array}$ & \\
\hline \multicolumn{2}{|c|}{$\begin{array}{l}\text { Cost structure } \\
\text { - employee salary } \\
\text { - production cost } \\
\text { - transportation costs (shipping cost) } \\
\text { operational costs (online marketing, etc.) }\end{array}$} & \multicolumn{2}{|c|}{$\begin{array}{l}\text { Revenue Stream } \\
\text { sales results of the wallets }\end{array}$} & \\
\hline
\end{tabular}

Figure 2 Business Model Canvas SARLEC \& SON'S

Based on the results of the canvas business model, it can be seen that in terms of Key Partners that Loud Wise products required suppliers of raw materials, craftsmen, and personal resellers who would sell these products to consumers. Key Activities on Loud Wise products included making product samples, selling via online/offline, creating new models, and updating news to customers. Key Resources in Loud Wise products consisted of physical offices, personal models, business licenses, and product brands. The value proposition that existed on Loud Wise products was genuine leather quality, varied designs, and handmade products. Customer Relationship used online media or call centers to respond to customer complaints, provide discounts for large or recurring purchases, and respond responsively to consumer complaints. Channel was used to get consumers through Instagram, Facebook, and Call Centers (WA, BBM, Line, Email). The customer segment wanted to get consumers from adolescents to adults (50 years). Cost Structure incurred during the production period were salary costs, production costs (machinery, raw materials, electricity), transportation costs (shipping goods to consumers/postage), and operational costs. Revenue streams obtained through the sale of wallets to consumers both online and offline. 
After mapping using Business Model Canvas, marketing analysis (7P), and STP (Segmentation, Target, Positioning), marketing analysis would then be performed. The explanation below related to the marketing mix and STP is as follows:

\section{Marketing Mix (7P)}

\section{a. Product dan Price}

Kotler and Keller (2007) explained that interpreting a product is anything that can be offered to the market to be considered, owned, used, or consumed so that it can satisfy the needs and desires of consumers. Pricing is influenced by product demand, target markets, competitor reactions, pricing strategies, other parts outside the marketing mix, and other operational costs. Pricing has several specific purposes. Tjiptono and Chandra (2004). Below is a list of products and prices for Loud Wise produced by UD Sarlec \& Son's as follows:

Table 1 List of Loud Wise Products and Prices

\begin{tabular}{|c|c|c|c|c|}
\hline No & Product & \multicolumn{2}{|c|}{ Kinds } & Price \\
\hline 1 & & $\begin{array}{l}\text { man's } \\
\text { from cow }\end{array}$ & $\begin{array}{l}\text { wallet } \\
\text { leather }\end{array}$ & Rp 150.000 \\
\hline 2 & & $\begin{array}{l}\text { man's } \\
\text { from } \\
\text { leather }\end{array}$ & $\begin{array}{c}\text { wallet } \\
\text { lizard }\end{array}$ & Rp 235.000 \\
\hline 3 & & $\begin{array}{l}\text { woman's } \\
\text { from cow }\end{array}$ & $\begin{array}{l}\text { wallet } \\
\text { leather }\end{array}$ & Rp 250.000 \\
\hline 4 & & $\begin{array}{l}\text { woman's } \\
\text { from } \\
\text { leather }\end{array}$ & $\begin{array}{c}\text { wallet } \\
\text { lizard }\end{array}$ & Rp. 350.000 \\
\hline
\end{tabular}

LOUD WISE itself is a product created by UD. SARLEC \& SON'S by making a product from leather, which is known for the quality and durability of the product. The average price is set starting from IDR 150,000 up to IDR 350,000. As a new product to enter an existing market (market follower), it cannot be easy to determine competitive prices, because prices can be the reach of customers for comparison of the quality of existing products.

b. Promotion

Promotion is one of the elements in the marketing mix that is very important to be carried out by companies in marketing their products. No matter how good a product is, if consumers have never heard of it and are not sure the product will be useful for them, then they will not buy it. Basically, promotion is all activities that intend to communicate and deliver a product to the market to provide information about privileges, the most important use is about its existence, to change attitudes, and encourage people to act (in 
terms of buying). The main purpose of promotion is to inform, influence, and persuade, and remind consumers. It is also to simplify the process of introducing new products, facilities in the form of electronic media, namely the internet, have shown much success in marketing products, especially in new products. It is because electronic media is easy to find anywhere and can indirectly be assumed that every consumer must have electronic media such as cellphones, television, computers, and other electronic media.

c. Place

Kotler and Keller (2007) explained that place is a strategy that determines where and how a certain product is sold. The most important thing in this strategy is determining the location, distributor, or outlet where consumers can see and buy the goods offered. It can be on social media like Facebook, Google Magazine, Instagram, and other social media. Until now, LOUD WISE markets its products using the website www.instagram.com/loud_wise/ or through an Instagram account @loud_wise.

\section{d. People}

The number of employees is still the amounting of five people who become permanent employees because the production division or marketing division still uses freelance services or services that are not related to UD. SARLEC \& SON'S.

\section{e. Process}

Payne (2006) explained definition of process is "creating and providing services to consumers is a major factor in the marketing mix." In a service management economy, customers will view the service delivery system as part of the service itself. Below is the business and production processes run by Loud Wise, as follows:

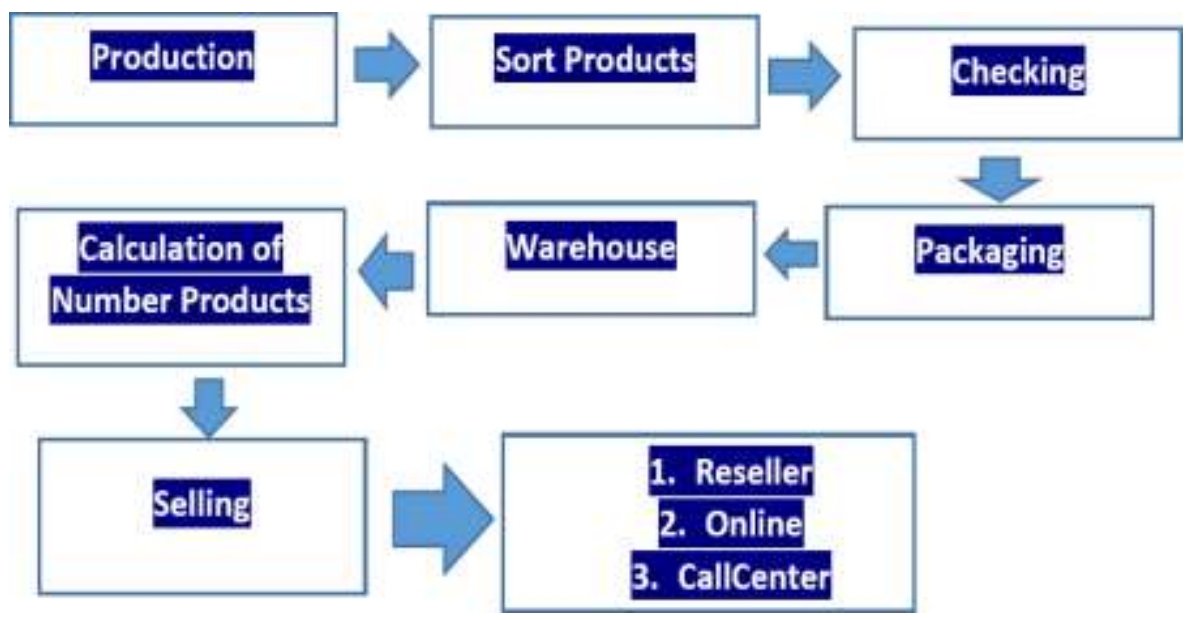

Figure 3 Loud Wise Business Process 


\author{
Azmy, Saputra, \& Sulistianto \\ Mapping Canvas Business Models for Marketing Loud Wise Leather Products
}

\title{
f. Physical Evidence
}

Yazid (1999) explained that physical evidence is the physical environment in which services are delivered and where companies and consumers interact and each component for the appearance or communication facilities of the services. The physical environment is a state or condition that also includes the atmosphere in which the service operates. The physical company of UD. SARLEC \& SON'S is a home industry, where for each division, it does not only rely on all parts of the company but also from external factors that aim to increase the communicative power of the surrounding community. The physical condition of the products supported by leather raw materials is sufficient to meet consumer expectations.

\section{Marketing Effort (SWOT Analysis)}

David (2011) defines a SWOT analysis is an important matching tool to assist managers in developing four types of strategies including Strengths-Opportunities (SO) strategies, Opportunities-Weaknesses (WO) strategies, Strengths-Threats (ST) strategies, and Weaknesses-Threats (WT) strategies that are tailored to the circumstances of the company. This analysis is based on logic related to developing mission, goals, strategies, and business policies for the best strategic decision making. There are two components in conducting a SWOT analysis. First, Internal Factor Analysis Strategy (IFAS) is an analysis of internal factors that affect the sustainability of the company, which is a strength, a condition, or an interconnected event where the organization/company can control it. The second, External Factor Analysis Strategy (EFAS), is an analysis of external factors that affect the sustainability of the company, which is a strength, a condition, an interconnected event where the organization/company does not have the ability or little ability to control or influence it.

This study provided four strategies that Loud Wise must undertake to increase market share and consumer segmentation. The SO (Strength-Opportunities) strategy illustrates that a company must maintain product quality by highlighting handmade production that continues to update the development of fashion globally from the price of goods, the origin of production, to the price class that determines product valuation from consumers. The ST (Strength-Threat) strategy provides stages for Loud Wise products by promoting products that are not only done through social media but also from physical forms such as owning a physical store, endorse, educating or continuously educating through creating useful articles containing product reviews both in terms of the materials used, and so forth. The WO (Weak-Opportunity) strategy provides a solution in gathering information on the development of the leather industry to design a marketing strategy, to expand market reach by conducting surveys of various objects, namely checking competitor's stores online, physically, and so forth. The WT (Weak-Threat) strategy explains by doing various types of selling ranging from online and physical types through several ways of promotion, ranging from endorse products through social media accounts, product trials 


\author{
Azmy, Saputra, \& Sulistianto \\ Mapping Canvas Business Models for Marketing Loud Wise Leather Products
}

by burning the wallet for a few moments to practice the durability of the product, provide sales programs such as discounts, and so on.

\title{
3. New Pricing Strategy
}

Pricing strategies usually change when the product goes through its life cycle. The introduction phase is very challenging. Companies that issue new products face the challenge of setting prices for the first time. The definition of a skimming pricing strategy is to set high prices for new products to darken the maximum revenue layer by layer from segments that are willing to pay high prices, companies make fewer but more profitable sales, and for price penetration strategies is to set low prices on new products to attract buyers in large numbers and create a large market share.

The price set for a new product must have a good influence on market growth, in addition to preventing fierce competition. With the price penetration strategy of setting a low price at the beginning of production, it aims to gain a large market share and simultaneously hinder the entry of competitors. The price penetration strategy is a low-price set with the same quality, which aims to promote LOUD WISE products. Indirectly with this pricing strategy program, UD. SARLEC \& SON'S can read or measure the level of purchasing power of consumers and expand the market on the LOUD WISE products. The programs carried out in market penetration besides setting low prices for initial sales are using a system of coupons or shopping vouchers specifically for LOUD WISE products, using LOUD WISE customer membership members, and so forth. Consumers, basically, have a price reference that aims at low prices, and they can match the criteria they want. Consumers are more interested in the price difference of $10 \%$ to $15 \%$ of the competing products that are not too expensive or low prices but have competitive quality. By using this strategy, LOUD WISE will be easily known to the public from prices that are not too expensive with competitive quality goods.

\section{Conclusion}

The conclusion of this study is that the Business Model Canvas was implemented for Loud Wise product marketing. The focus of this research is how companies were able to increase product promotion and introduction to consumers. Companies must be able to know how the preference and business trends desired by consumers. Implementation of Business Model Canvas would be able to explain the components that must be fixed and improved in carrying out business processes in a sustainable manner. Loud Wise products must continuously adapt to the development and needs of consumers. The right marketing tactics or strategies can increase profitability according to company expectations. Mapping the components of the business model appropriately can provide the right solutions and recommendations so that it can compete with other competitors. 


\section{Azmy, Saputra, \& Sulistianto \\ Mapping Canvas Business Models for Marketing Loud Wise Leather Products}

\section{References}

Abedin M. Z., Rahman, M. N., \& Mohiuddin. (2016). Application of Customer Driven Marketing Strategies in Banking Industry and Perception of Customers: A Study on Pubali Bank Limited. IOSR Journal of Business and Management, 18(11), 50-63.

Afifuddin. (2014). Pengantar Administrasi Pembangunan. Bandung: CV Alfabeta.

Cravens, D. (1997). Strategic Marketing Alih Bahasa Lina Salim Edisi keempat. Jakarta: Erlangga.

David, F. R. (2011). Manajemen Strategis Edisi 12. Jakarta : Salemba Empat.

Hanurawan, F. (2012). Metode Penelitian Kualitatif dalam Ilmu Psikologi. Surabaya: Komisi Peningkatan Kinerja Masyarakat (KPKM) Universitas Airlangga.

Johnson, B., \& Chirstensen, L. (2004). Educational Research Quantitative, Qualitative, and Mixed Approaches. Boston : Pearson.

Karakaya, C.., Badur, B., \& Aytekin, C. (2012). Analyzing the Effectiveness of Marketing Strategies in the Presence of Word of Mouth: Agent-Based Modeling Approach. Journal of Marketing Research and Case Studies, 1-17.https://doi.org/10.5171/2011.421059.

Keegan \& Green. (2008). Global Marketing. Edisi 5. London: Pearson Education.

Kotler, P., Keller, K. L. (2007). Manajemen Pemasaran. Jilid 1 dan 2 (Terjemahan). Jakarta: Penerbit Indeks

Kumar, V., \& Petersen, J. A. (2005). Using a Customer-Level Marketing Strategy to Enhance Firm Performance: A Review of Theoretical and Empirical Evidence. Journal of the Academy of Marketing Science, 33(4), 504-519

Lovelock, C. (2015). Service Marketing Text Cases and Readings Prentice-Hall Englewood Cliffs. New Jersey.

Oliver, R. L. (2015). Satisfaction: A Behavioral Perspective on the Consumer. In Satisfaction: A Behavioral Perspective on the Consumer. https://doi.org/10.4324/9781315700892

Osterwalder, A. \& Pigneur, Y. (2012). Business Model Generation. New Jersey: John Wiley \& Sons, Incorporation.

Payne, A. (2006). Service Marketing Pemasaran Jasa. 2013. Analisis SWOT : Teknik Membedah Kasus. Rangkuti : Yogyakarta, Freddy. Jakarta : PT Gramedia.

Tambunan, T. (2013). UMKM di Indonesia. Bogor: Ghalia Indonesia.

Tjiptono, F., \& Chandra, G. (2004). Service, Quality dan Satisfaction. Yogyakarta; Andi. Jurnal of Business and Management Sciences, 4(4), 76-81.

Tohirin. (2012). Metode Penelitian Kualitatif dalam Pendidikan dan Bimbingan Konseling Pendekatan Praktis Untuk. Peneliti Pemula dan Dilengkapi dengan Contoh Transkrip hasil Wawancara Serta Model Penyajian Data. Jakarta : Rajawali Pers.

Tood, A. M. (2012). Strategic Marketing. International edition. New Jersey: Pearson.

Yazid. (1999). Pemasaran Jasa: Konsep dan Implementasi. Yogyakarta : Ekonisia FE UII

Zeithaml, V. A. (2010). Of Consumer Perceptions A Means-End Value : Quality, and Model Synthesis of Evidence. Synthesis, 52(3), 2-22. 